\title{
Tanshinone IIA acts via p38 MAPK to induce apoptosis and the down-regulation of ERCC1 and lung-resistance protein in cisplatin-resistant ovarian cancer cells
}

\author{
JIN-WEN JIAO and FANG WEN
}

\author{
Department of Gynecology, The First Affiliated Hospital of China Medical University, \\ Shenyang 110001, Liaoning, P.R. China
}

Received September 1, 2010; Accepted October 27, 2010

DOI: 10.3892/or.2010.1107

\begin{abstract}
Tanshinone IIA is known to induce apoptosis in several types of cancer cells. However, little is known about its activity in chemoresistant cells. The aim of this study was to investigate the anticancer properties of tanshinone IIA in cisplatin-resistant human ovarian cancer COC1/DDP cells in vitro. We used a variety of methods to measure cell viability, the resistance index (RI) of cisplatin, cellular apoptosis, p38 mitogen-activated protein kinase (MAPK) expression and phosphorylation, and the mRNA expression of several genes implicated in drug resistance including survivin, Caspase-3, excision repair cross-complementing gene 1 (ERCC1), multidrug resistance (MDR), lung resistance protein (LRP) and glutathione-S-transferase- $\pi$ (GST- $\pi$ ). We found that tanshinone IIA time- and dose-dependently inhibited the proliferation of COC1/DDP cells and caused significant apoptosis. Western blotting revealed that tanshinone IIA also increased phospho-p38 MAPK in a time- and dose-dependent manner. After treatment by tanshinone IIA for $48 \mathrm{~h}$, the RI of cisplatin and the mRNA expression of survivin, ERCC1 and LRP were all significantly decreased. Furthermore, blockade of p38 signal transduction decreased apoptotic cell rates and dramatically elevated the mRNA expression of the survivin, ERCC1 and LRP genes. We therefore conclude that tanshinone IIA induces apoptosis and reduces cisplatin resistance in COC1/DDP cells and thus causes significant growth inhibitory effects. This mechanism appears to involve p38mediated downregulation of survivin, ERCC1 and LRP mRNA expression.
\end{abstract}

Correspondence to: Professor Fang Wen, Department of Gynecology, The First Affiliated Hospital of China Medical University, Shenyang 110001, Liaoning, P.R. China

E-mail: wenfang64@hotmail.com

Key words: tanshinone IIA, cisplatin resistance, ovarian cancer, p38 mitogen-activated protein kinase, survivin, excision repair cross-complementing gene 1 , lung resistance protein

\section{Introduction}

Ovarian cancer is the most commonly diagnosed and lethal gynecological malignancy. The high mortality rate is attributed in part to the lack of early detection systems, but is largely due to the development of chemoresistance $(1,2)$. Although platinum-based compounds (e.g. cisplatin) in combination with taxanes are initially effective, the five-year survival rates are only about $50 \%$ (3). Although most ovarian tumors are initially sensitive to chemotherapy, the development of recurrent tumors that are resistant to cisplatin remains a major hurdle to successful therapy and is responsible for poor long-term overall survival $(3,4)$. Cellular resistance to cisplatin is a complex phenomenon involving multiple adaptations such as increased defense mechanisms [e.g. multidrug resistance gene (MDR), lung resistance protein (LRP), glutathione-S-transferase- $\pi$ (GST- $\pi$ )], augmentation of DNA repair [e.g. excision repair cross-complementing gene 1 (ERCC1)], and inhibition of apoptosis (e.g. members of the caspase family) $(5,6)$. Moreover, activation of cell pathways (e.g. the p38 mitogen-activated protein kinase (MAPK) pathway) is a common feature of cancer cells and could influence the cellular response after drug treatment $(7,8)$.

Tanshinone IIA, a phenanthrenequinone derivative isolated from Danshen (Salvia miltiorrhiza bunge), has anti-oxidant properties, inhibiting the association of lipid peroxidation products with DNA by breaking the chain reactions of peroxidation by scavenging lipid free radicals (9-11). Recent studies have shown that tanshinone IIA has significant antiproliferation effects by inducing apoptosis against multiple human cancer cell lines such as those derived from human breast cancer (12), hepatocellular carcinoma (13) and leukemia (14). Although the anti-cancer effects of tanshinone IIA have been studied in various cancer cells, it remains unknown whether it produces similar effects on drug-resistant cells such as cisplatin-resistant ovarian cancer cells. Therefore, the aim of this study was to elucidate the effects of tanshinone IIA on these cells and to identify its mechanism of action. Our results showed that tanshinone IIA induces apoptosis in cisplatin-resistant ovarian cancer cells and reduces resistance in these cells by downregulating survivin, ERCC1 and LRP. This downregulation was mediated by activation of $\mathrm{p} 38$ 
MAPK. Tanshinone IIA thus enhanced the apoptotic rate induced by cisplatin and attenuated cisplatin-induced upregulation of survivin and LRP expression in cisplatinresistant ovarian cancer cells.

\section{Materials and methods}

Reagents. Tanshinone IIA was purchased from Xi'an Guanyu Bio-Tech Company. Cisplatin was obtained from Shandong Qilu Pharmaceutical Factory. Rabbit anti-phospho-p38 polyclonal antibody and rabbit anti-p38 polyclonal antibody were from Santa Cruz Biotechnology (Santa Cruz, CA). The p38 inhibitor, SB203580, was supplied by Calbiochem (La Jolla, CA). RPMI-1640 medium was purchased from Hyclone Company (Logan, UT). MTT [3-(4, 5-dimethylthiazol-2-yl)2, 5-diphenyltetrazolium bromide] was obtained from Sigma (St. Louis, MO). All other chemicals and drugs were from Sigma Chemicals (St. Louis, MO).

Cell culture. COC1 (cisplatin-sensitive human ovarian epithelial carcinoma cell line) and COC1/DDP (cisplatinresistant cell line) cells were obtained from China Center for Type Culture Collection) and cultured in RPMI-1640 containing $10 \%$ fetal bovine serum (FBS) and penicillin/ streptomycin $(100 \mathrm{U} / \mathrm{ml})$ in a humidified $37^{\circ} \mathrm{C}$ incubator. For the inhibition experiments, cells were pretreated with the p38 MAPK inhibitor, SB203580, for $1 \mathrm{~h}$ prior to stimulation with tanshinone IIA at $8 \mathrm{mg} / \mathrm{ml}$ for $48 \mathrm{~h}$.

Cell viability. Cell viability was assayed using the MTT assay. Briefly, $1 \times 10^{4}$ COC1/DDP cells per well were dispensed into 96-well culture plates in $100 \mu 1$ volumes. A range of concentrations of tanshinone IIA $(1,2,4,8$ and $16 \mu \mathrm{g} / \mathrm{ml})$ was added to designated wells. Vehicle buffer was added to an additional group of wells to act as a control sample. Each of the groups (treated and control) contained four adjacent wells. Plates were incubated for 1, 2, 3, 4, 5 and $6 \mathrm{~d}$ prior to addition of $20 \mu \mathrm{l}$ of MTT working solution $(5 \mathrm{mg} / \mathrm{ml})$ and a further $4 \mathrm{~h}$ incubation. Plates were then centrifuged (10 min, $2000 \mathrm{x} \mathrm{g}$ ) and culture medium supernatant was removed and replaced with $100 \mu 1$ of DMSO to solubilize the cells. The absorbance (A value) of each well was measured using a microplate reader at $570 \mathrm{~nm}$. Cell viability was calculated according to the formula:

$$
\text { Viability rate }=\frac{100 \times A_{t}}{A_{\text {con }}}
$$

where $A_{\text {con }}$ is the $A$ value of the control group and $A_{t}$ is the $A$ value of the treatment group. All experiments were repeated independently at least 3 times.

Resistance index (RI) of cisplatin. The RI of cisplatin in COC1/DDP cells was also assayed using the the MTT assay. COC1 and COC1/DDP cells were seeded in 96-well plates at $1 \times 10^{4}$ cells per well. A range of concentrations of cisplatin $(10,20,40,80$ and $100 \mathrm{nmol} / \mathrm{ml})$ was then applied to designated wells, and buffer applied to control wells. Each condition was repeated in quadruplicate. After a $48 \mathrm{~h}$ incubation period, cells were incubated for a further $4 \mathrm{~h}$ following addition of $20 \mu \mathrm{l}$ MTT working solution $(5 \mathrm{mg} / \mathrm{ml})$. Cells were then solubilized and prepared for absorbance reading as described above. Cell inhibitory rate was calculated according to the formula:

$$
\text { Inhibitory rate }=\frac{100 \times\left(A_{\text {con }}-A_{t}\right)}{A_{\text {con }}}
$$

where $A_{\text {con }}$ is the $A$ value of the control group and $A_{t}$ is the A value of the treatment group. The $50 \%$ inhibitory concentration $\left(\mathrm{IC}_{50}\right)$ was determined from dose-response data from at least three independent experiments. $\mathrm{The} \mathrm{IC}_{50}$ values were calculated in each independent experiment and an average value obtained by calculating the mean of these $\mathrm{IC}_{50}$ values. The COC1/DDP cell RI of cisplatin was calculated according to the formula:

$$
\mathrm{RI}=\frac{\mathrm{IC} 50_{\mathrm{COC} 1 / \mathrm{DDP}}}{\mathrm{IC} 50_{\mathrm{COC} 1}}
$$

where $\mathrm{IC} 50_{\mathrm{COC} 1 / \mathrm{DDP}}$ is the $\mathrm{IC}_{50}$ value in the cisplatin-resistant COC1/DDP cells and $\mathrm{IC} 50_{\mathrm{COC} 1}$ is the $\mathrm{IC}_{50}$ in the cisplatinsensitive $\mathrm{COC} 1$ cells. This assay was then repeated in the presence of tanshinone IIA $(8 \mu \mathrm{g} / \mathrm{ml})$. All experiments were repeated at least three times independently.

Flow cytometry analysis for cell apoptosis. For FCM analysis, $1 \times 10^{6}$ cells treated with cisplatin, SB203580 or different concentrations of tanshinone IIA were harvested, collected by centrifugation $(10 \mathrm{~min}, 2000 \mathrm{x} \mathrm{g})$ and washed three times with phosphate-buffered saline (PBS) at $4^{\circ} \mathrm{C}$. Prior to analysis, cells were resuspended in binding buffer (10 mM Hepes/ $\mathrm{NaOH}, \mathrm{pH} 7.4,140 \mathrm{mM} \mathrm{NaCl}, 2.5 \mathrm{mM} \mathrm{CaCl})$. Cells were then incubated with $5 \mu \mathrm{l}$ Annexin V-FITC for $3 \mathrm{~min}$ and with $20 \mathrm{ng} / \mathrm{ml}$ propidium iodide in the dark for $15 \mathrm{~min}$. This suspension was analyzed by flow cytometry (BectonDickinson, San Jose, CA). All data were collected and analyzed by Lysis II $^{\mathrm{TM}}$ software (Becton-Dickinson). The experiments were repeated three times independently and the results were presented as the mean \pm standard deviation.

Preparation of cytosolic proteins and Western blot analysis. Following treatment, cells were washed twice with ice-cold PBS and pelleted by centrifugation ( $3 \mathrm{~min}, 2000 \mathrm{x} \mathrm{g}$ ) before homogenization in ice-cold fractionation buffer (50 mM Tris$\mathrm{HCl}, \mathrm{pH}$ 7.4, 1 mM EDTA, $150 \mathrm{mM} \mathrm{NaCl}, 1 \%$ TritonX-100, $1 \mathrm{mM}$ PMSF, $10 \mu \mathrm{g} / \mathrm{ml}$ leupeptin, $10 \mu \mathrm{g} / \mathrm{ml}$ pepstatin A, $10 \mu \mathrm{g} / \mathrm{ml}$ aprotinin, $1 \mathrm{mM}$ sodium orthovanadate $\left[\mathrm{Na}_{3} \mathrm{VO}_{4}\right]$, $10 \mathrm{mM}$ sodium pyrophosphate $\left[\mathrm{Na}_{4} \mathrm{P}_{2} \mathrm{O}_{7}\right]$ and $50 \mathrm{mM}$ sodium fluoride $[\mathrm{NaF}])$. This cell lysate was incubated on ice for $15 \mathrm{~min}$ and centrifuged at $20,000 \mathrm{x}$ g for $30 \mathrm{~min}$ at $4^{\circ} \mathrm{C}$. The cytosolic fraction was collected and subjected to SDS-PAGE with a $10 \%$ running gel. Protein concentrations were determined using a BCA Protein assay kit (Pierce, Rockford, IL). The proteins were transferred to a polyvinylidene fluoride membrane which was then blocked by incubation with $5 \%$ 
Table I. Forward and reverse primers used for quantitative RT-PCR.

\begin{tabular}{|c|c|}
\hline Gene & Sequence \\
\hline \multirow[t]{2}{*}{ Human MDR } & Forward: 5'-GGAGCGGTTCTACGA-3' \\
\hline & Reverse: 5'-ACGATGCCCAGGTGT-3' \\
\hline \multirow[t]{2}{*}{ Human ERCC1 } & Forward: 5'-ACCGTGAAGTCAGTCAACAAA-3' \\
\hline & Reverse: 5'-TCGTGCAGGACATCAAACA-3' \\
\hline \multirow[t]{2}{*}{ Human GST- $\pi$} & Forward: 5'-CTGGAAGGAGGAGGTGGTG-3' \\
\hline & Reverse: 5'-GACGCAGGATGGTATTGGAC-3' \\
\hline \multirow[t]{2}{*}{ Human LRP } & Forward: 5'-GGCTCCTTCCGCTACGT-3' \\
\hline & Reverse: 5'-GCCGAGACCGCTCAATAC-3' \\
\hline \multirow[t]{2}{*}{ Human Caspase-3 } & Forward: 5'-GTGGCATTGAGACAGAC-3' \\
\hline & Reverse: 5'-GGCACAAAGCGACTG-3' \\
\hline \multirow[t]{2}{*}{ Human survivin } & Forward: 5'-CTGCGGAGAAAGTGCG-3' \\
\hline & Reverse: 5'-GGGAATAAACCCTGGAAG-3' \\
\hline \multirow[t]{2}{*}{ Human $B$-actin } & Forward: 5'-AAGGCTGTGGGCAAGG-3' \\
\hline & Reverse: 5'-TGGAGGAGTGGGTGTCG-3' \\
\hline
\end{tabular}

bovine serum albumin in Tris-buffered saline containing $0.05 \%$ Tween-20 (TTBS) at room temperature for $1 \mathrm{~h}$. Different primary antibodies (in TTBS) were applied at $4^{\circ} \mathrm{C}$ for $12 \mathrm{~h}$ followed by horseradish peroxidase-conjugated secondary antibody at room temperature for $1 \mathrm{~h}$. Membrane was washed extensively with TTBS between blocking, primary and secondary antibody stages.

RNA extraction and quantitative real-time PCR analysis. Total RNA was isolated using Trizol reagent (Sigma Chemical) according to the manufacturer's instructions. Total RNA $(2 \mu \mathrm{g})$ was reverse-transcribed using a Promega (Madison, WI) reverse transcription system. The forward and reverse PCR primers used are summarized in Table I.

Reaction mixture $(1 \mu \mathrm{l})$ was subjected to PCR. The amount of PCR product formed in each cycle was evaluated on the basis of SYBR Green I fluorescence. All amplification reactions were performed using the Mx3000 Multiplex Quantitative PCR system (Stratagene, La Jolla, CA) with the following cycle conditions: one cycle at $95^{\circ} \mathrm{C}$ for $5 \mathrm{~min}$, followed by 40 cycles at $95^{\circ} \mathrm{C}$ for $30 \mathrm{sec}, 58^{\circ} \mathrm{C}$ for $30 \mathrm{sec}$ and $72^{\circ} \mathrm{C}$ for $30 \mathrm{sec}$. Results were analyzed with Stratagene Mx3000 software and the mRNA level for each gene was normalized to $\beta$-actin levels. PCR reactions were performed in duplicate and each experiment was repeated independently three times.

Statistical analysis. Quantitative data are presented as the mean \pm SD determined from the indicated number of experiments. Statistical analysis was based on Student's t-test for comparison of two groups or one-way ANOVA followed by a least squares difference (LSD) test for comparison of multiple groups.

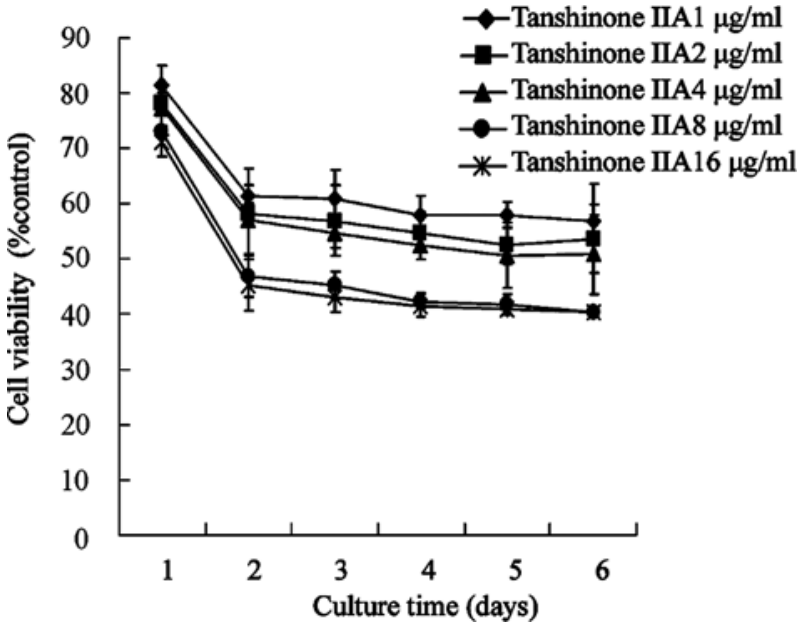

Figure 1. Tanshinone IIA inhibits the growth of cisplatin-resistant ovarian cancer cells. COC1/DDP cells were treated with different concentrations of Tanshinone IIA, and viability was determined using the MTT assay as described in Materials and methods. Values are expressed as mean \pm SD $(n=3)$.

\section{Results}

Cell growth rate of COC1/DDP was inhibited by tanshinone IIA. Tanshinone IIA $(1,2,4 \mu \mathrm{g} / \mathrm{ml})$ had little inhibitory effect on COC1/DDP cells. However, higher concentrations of this agent ( 8 and $16 \mu \mathrm{g} / \mathrm{ml})$ significantly inhibited their proliferation. The inhibitory rate of tanshinone IIA at concentrations between $8-16 \mu \mathrm{g} / \mathrm{ml}$ is much higher than that of lower concentrations $(\mathrm{p}<0.05)$. Viability was relatively high on the first day but decreased significantly from day 2 onwards $(\mathrm{p}<0.05)$ (Fig. 1). The $\mathrm{IC}_{50}$ values after 1, 2, 3, 4, 5 and 6 days of treatment were 98.14, 7.23, 5.45, 3.82, 3.23 and $3.09 \mu \mathrm{g} / \mathrm{ml}$, respectively.

RI of cisplatin in COC1/DDP cells is reduced after treatment with tanshinone IIA. The inhibition of cell growth by cisplatin is appreciably reduced in the cisplatin-resistant COC1/DDP cells compared with the cisplatin-sensitive COC1 cells. However, in the presence of tanshinone IIA, the sensitivity to cisplatin-mediated growth inhibition appears to be restored to a level similar to that in COC1 cells (Fig. 2A). Furthermore, the resistance index (RI) of cisplatin the COC1/DDP cells is significantly reduced by the presence of tanshinone IIA (Fig. 2B), confirming that tanshinone dramatically reduces the resistance of these cells to cisplatin cytotoxicity.

COC1/DDP cell apoptosis caused by tanshinone IIA. As shown in Fig. 3, the presence of tanshinone IIA for 24-72 h caused an increase in the rate of apoptosis in COC1/DDP cell cultures. At $24 \mathrm{~h}$, there was a small but significant $(\mathrm{p}<0.05)$ increase in apoptosis induced by $8 \mu \mathrm{g} / \mathrm{ml}$ tanshinone IIA (Fig. 3). This effect was considerably enhanced at 48 and $72 \mathrm{~h}(\mathrm{p}<0.01)$. A higher concentration $(16 \mu \mathrm{g} / \mathrm{ml})$ of tanshinone IIA also significantly $(\mathrm{p}<0.01)$ increased apoptosis rate at $48 \mathrm{~h}$ (Fig. 3) but a lower concentration $(4 \mu \mathrm{g} / \mathrm{ml})$ had no significant effect.

In COC1/DDP cells treated with cisplatin $(20 \mu \mathrm{M})$ in combination with tanshinone IIA $(8 \mu \mathrm{g} / \mathrm{ml})$, the rate of 

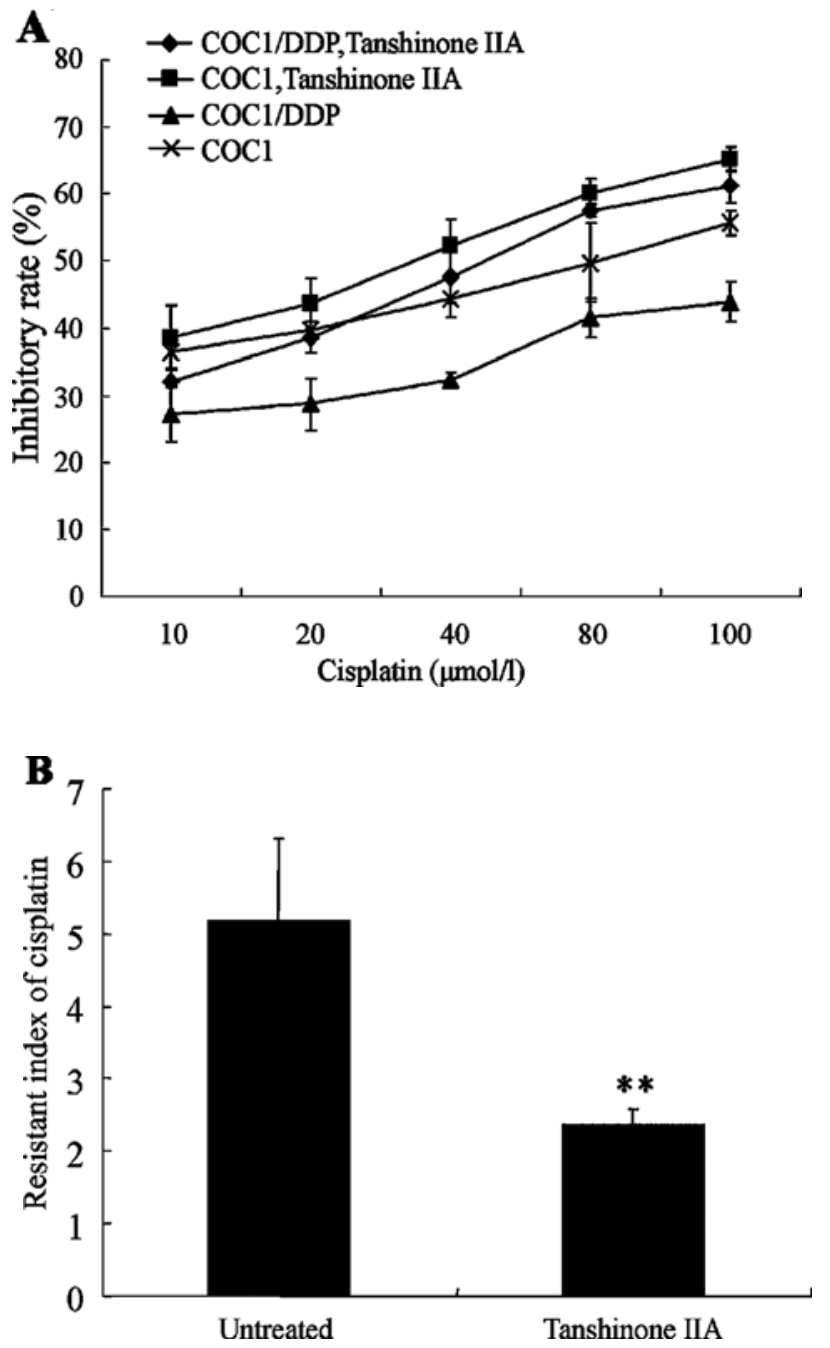

Figure 2. Modulation of cisplatin-mediated growth inhibition and resistance index by tanshinone IIA. COC1 and COC1/DDP cells were exposed to increasing concentrations of cisplatin for $48 \mathrm{~h}$ in the presence or absence of tanshinone IIA $(8 \mu \mathrm{g} / \mathrm{ml})$. Cell growth was assessed using an MTT assay. (A) The rate of growth inhibition in each cell line in the presence and absence of tanshinone IIA. (B) Resistance index (RI) of cisplatin in COC1/DDP cells in the presence and absence of tanshinone IIA. Values are expressed as mean $\pm \mathrm{SD}(\mathrm{n}=3)$. Data in (B) were analyzed using Student's t-test. ${ }^{* *} \mathrm{p}<0.01$, statistically significant difference.

apoptosis was significantly $(\mathrm{p}<0.01)$ higher than that in the presence of cisplatin alone (Fig. 4). A $1 \mathrm{~h}$ pre-treatment with the p38 MAPK inhibitor, SB203580 $(10 \mu \mathrm{M})$, resulted in a total blockade of the tanshinone IIA-mediated increase in apoptotic rate. This suggests that tanshinone IIA employs a p38-dependent signaling mechanism to modulate cellular apoptosis.

Tanshinone IIA enhances p38 MAPK activation of COC1/ DDP cells. We investigated the effect of tanshinone IIA on p38 MAPK activity in COC1/DDP cells using a Western blot technique. Phosphorylation of p38 MAPK in COC1/DDP cells was significantly increased by tanshinone IIA in a timedependent (Fig. 5) and dose-dependent (Fig. 6) manner.

Treatment of COC1/DDP cells with a combination of tanshinone IIA $(8 \mu \mathrm{g} / \mathrm{ml})$ and cisplatin $(20 \mu \mathrm{M})$ caused a

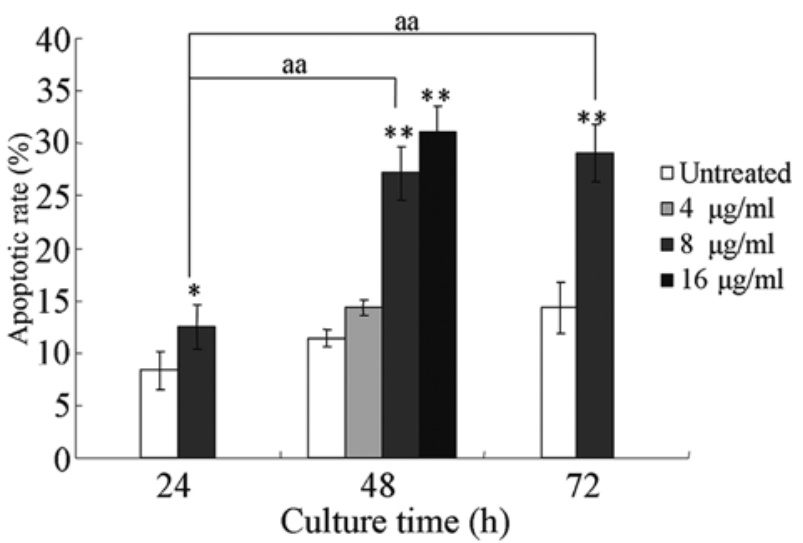

Figure 3. Rate of cell apoptosis caused by tanshinone IIA. COC1/DDP cells were treated with different concentrations of tanshinone IIA and cell apoptosis was analyzed by flow cytometry at various time points. Values are expressed as the mean \pm SD $(n=3)$. Statistical significance was assessed by one-way ANOVA followed by least squares difference (LSD) analysis. ${ }^{*} \mathrm{p}<0.05$ vs. untreated cells; ${ }^{* *} \mathrm{p}<0.01$ vs. untreated cells; ${ }^{\text {aa }} \mathrm{p}<0.01$ vs. cells treated by tanshinone IIA $(8 \mu \mathrm{g} / \mathrm{ml}, 24 \mathrm{~h})$.

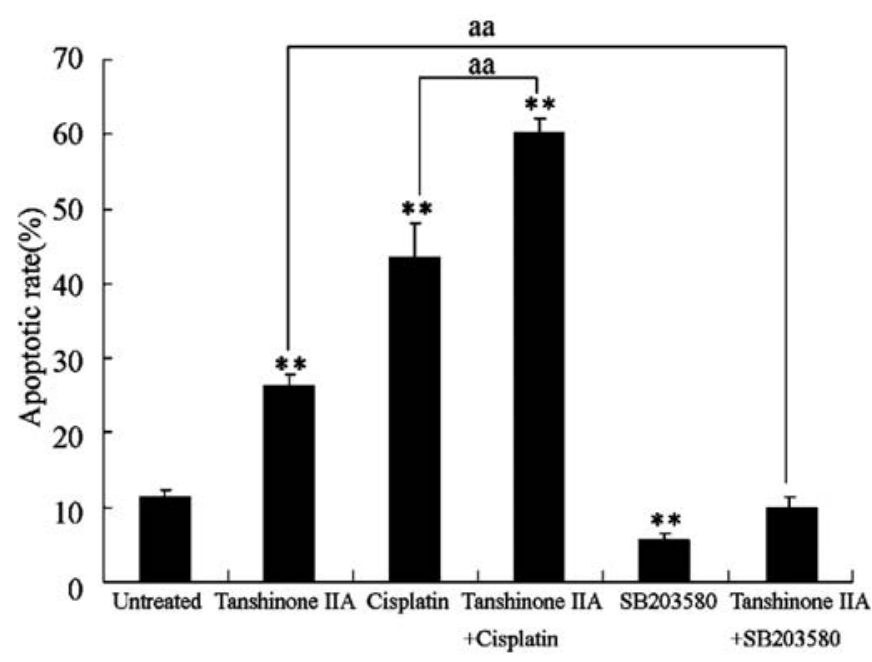

Figure 4. Modulation of apoptosis by tanshinone IIA and cisplatin, and the role of $\mathrm{p} 38$. COC1/DDP cells were treated with cisplatin $(20 \mu \mathrm{M})$, tanshinone IIA $(8 \mu \mathrm{g} / \mathrm{ml})$, or a combination of these two compounds. In addition, some cells were treated with vehicle or tanshinone IIA in the presence of the p38 inhibitor, SB203580 $(10 \mu \mathrm{M})$. Cellular apoptosis was then assessed by flow cytometry. Values are expressed as the mean \pm SD $(n=3)$. Statistical significance was assessed by one-way ANOVA followed by least squares difference (LSD) analysis. ${ }^{* *} \mathrm{p}<0.01 \mathrm{vs}$. untreated cells; ${ }^{\text {aa }} \mathrm{p}<0.01$ between column pairs as indicated.

significantly $(\mathrm{p}<0.01)$ greater increase in phospho-p38 than either agent alone (Fig. 7).

Survivin, ERCC1 and LRP MRNA expression in COC1/DDP cells is downregulated by Tanshinone IIA. To investigate the mechanism of Tanshinone IIA's effect on COC1/DDP cells, we used real-time PCR analysis to examine the mRNA expression of survivin, Caspase-3, ERCC1, LRP, MDR and GST- $\pi$, after treatment with tanshinone IIA $(8(\mathrm{~g} / \mathrm{ml})$ for $48 \mathrm{~h}$. The results showed significant downregulation in the 


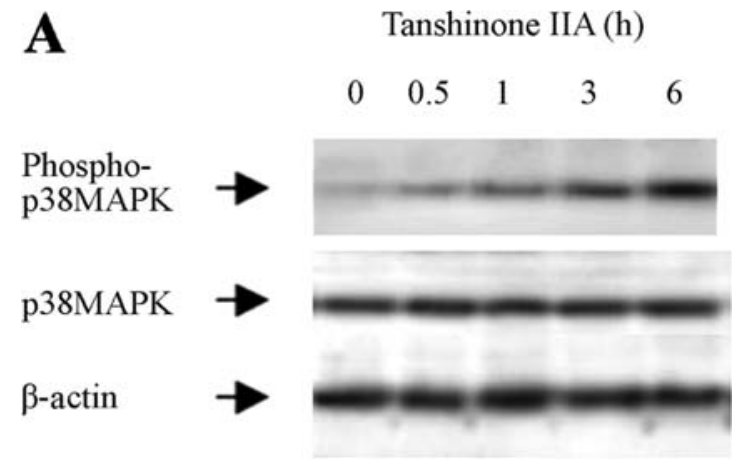

B

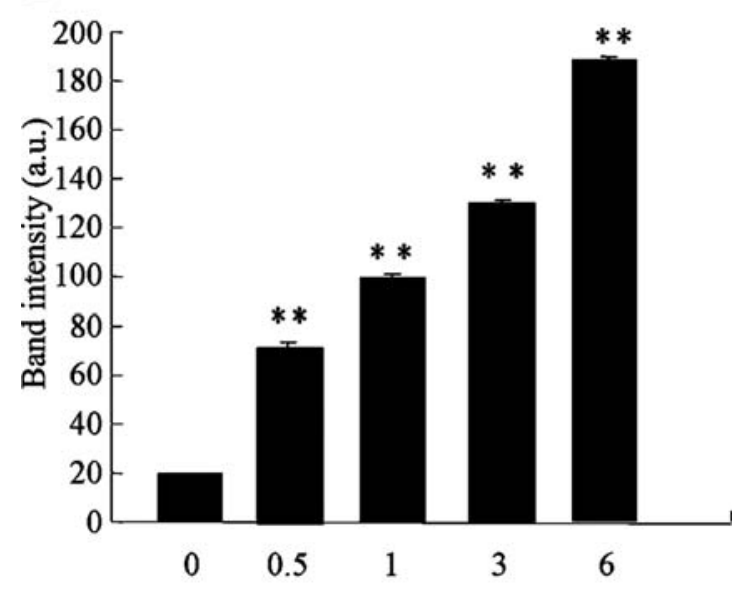

Tanshinone IIA culture time (h)

Figure 5. Western blot analysis of p38 MAPK and phospho-p38 MAPK cultured with tanshinone IIA for various time periods. (A) a representative image of a Western blot from this experiment. (B) densitometric data quantifying band density in our blots. Values are expressed as the mean \pm SD $(n=3)$. Data were analyzed statistically using one-way ANOVA followed by least squares difference (LSD) analysis. ${ }^{* *} \mathrm{p}<0.01$ vs. control.

mRNA expression of survivin $(\mathrm{p}<0.05)$, ERCC1 $(\mathrm{p}<0.01)$, $\operatorname{LRP}(\mathrm{p}<0.01)$ and GST- $\pi(\mathrm{p}<0.01)$ in response to tanshinone IIA compared with control cells (Fig. 8), while Caspase-3, MDR and was not.

p38-MAPK inhibitor, SB203580, attenuated tanshinone IIA-induced downregulation of survivin, ERCCI and LRP expression in COC1/DDP cells. We incubated cells with tanshinone IIA $(8 \mu \mathrm{g} / \mathrm{ml})$ in the presence of SB203580 $(10 \mu \mathrm{M})$ to investigate whether p38 MAPK was involved in the tanshinone IIA-induced downregulation of survivin, ERCC1 and LRP expression. As shown in Fig. 8, SB203580 not only significantly blocked tanshinone IIA-induced downregulation of survivin, ERCC1 and LRP expression $(\mathrm{p}<0.01)$ but indeed causes a huge upregulation of the expression of these mRNAs (Fig. 8).

Tanshinone IIA attenuated cisplatin-induced upregulation of survivin and LRP expression in COC1/DDP cells. As shown in Fig. 8, tanshinone IIA significantly attenuated the cisplatininduced upregulation of survivin $(\mathrm{p}<0.05)$ and LRP $(\mathrm{p}<0.01)$ expression.

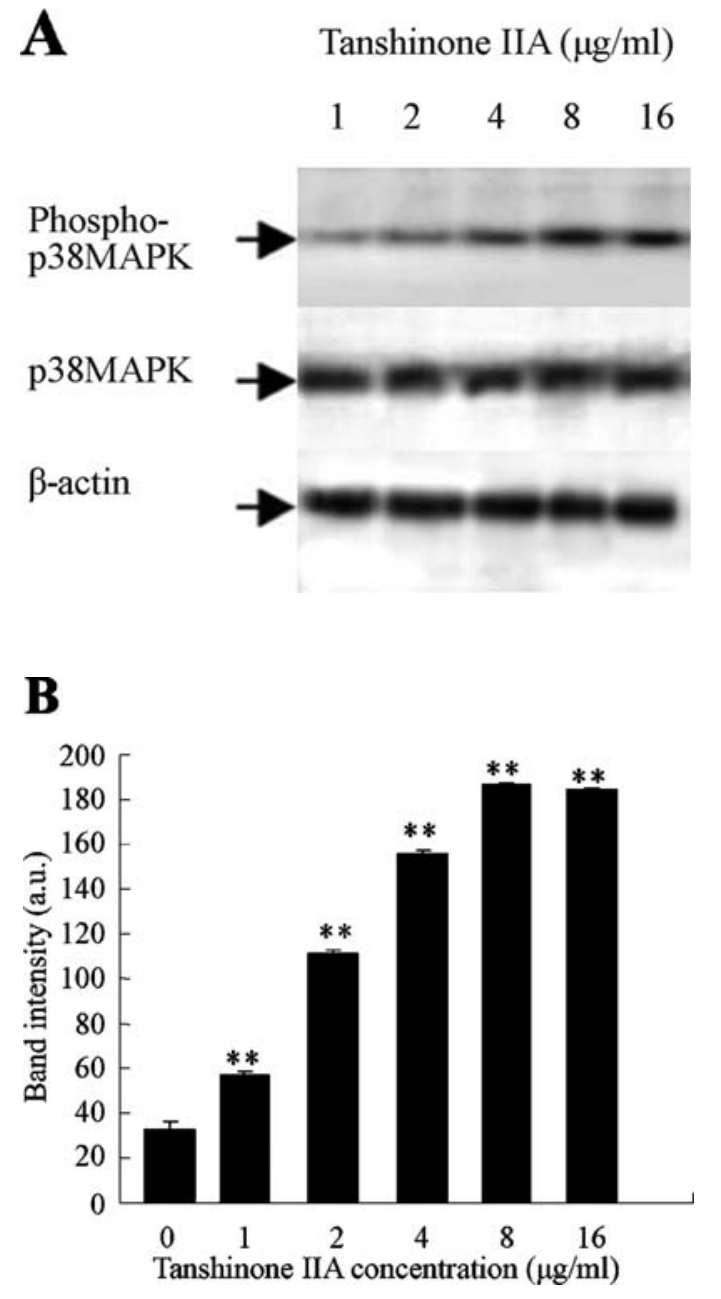

Figure 6. Western blot analysis of p38 MAPK and phospho-p38 MAPK cultured with various concentrations of tanshinone IIA. (A) a representative image of a Western blot from this experiment. (B) densitometric data quantifying band density in our blots. Values are expressed asthe mean \pm SD $(n=3)$. Data were analyzed statistically using one-way ANOVA followed by least squares difference (LSD) analysis to compare each column to the control column. ${ }^{* *} \mathrm{p}<0.01$ vs. control.

\section{Discussion}

The present study demonstrated that tanshinone IIA can induce apoptosis and downregulation of drug resistance genes in cisplatin-resistant ovarian cancer cells via p38 MAPK.

Resistance to drug therapy represents a major limitation to the efficacy of platinum-based therapies in different malignancies. In ovarian cancers, $>70 \%$ of patients initially respond to therapy with platinating agents. However, these patients often quickly develop resistance: the five-year survival rate for ovarian carcinoma is $<25 \%$ (15). Resistance can develop as a result of decreased influx or increased efflux of drug (MDR, LRP), glutathione or metallothionein conjugation (GST- $\pi$ ), drug detoxification, DNA repair, or skipping lesions during DNA replication (ERCC1), and inhibition of apoptosis $(5,6)$. Moreover, activation of survival pathways is a common feature of cancer cells and could influence the cellular response after drug treatment (p38 MAPK) $(7,8)$.

Tanshinone IIA, a derivative of phenanthrenequinone isolated from Danshen, is now widely used in the treatment 

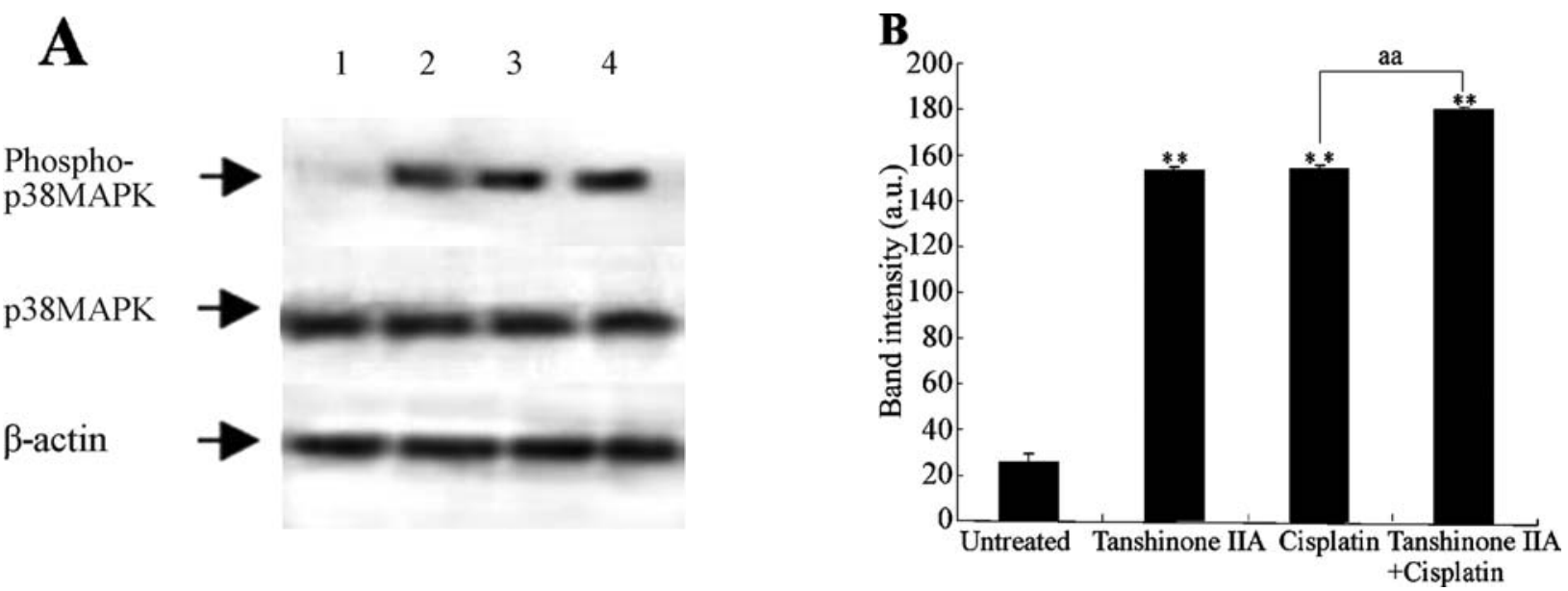

Figure 7. (A) Lane 1, untreated; lane 2 , tanshinone IIA $(8 \mu \mathrm{g} / \mathrm{ml})$; lane 3 , cisplatin $(20 \mu \mathrm{M})$; lane 4 , Tanshinone IIA $(8 \mu \mathrm{g} / \mathrm{ml})+$ cisplatin $(20 \mu \mathrm{M})$. Western blot analysis of p38 MAPK and phospho-p38 MAPK in COC1/DDP cells following treatment with tanshinone IIA ( $8 \mu \mathrm{g} / \mathrm{ml})$ and/or cisplatin (20 $\mu \mathrm{M}$. Values are expressed as the mean $\pm \mathrm{SD}(\mathrm{n}=3)$. Data were analyzed using one-way ANOVA followed by least squares difference (LSD) analysis to compare all pairs of columns. ${ }^{* *} \mathrm{p}<0.01$ vs. untreated cells; ${ }^{\text {aa }} \mathrm{p}<0.01$ between indicated pairs.

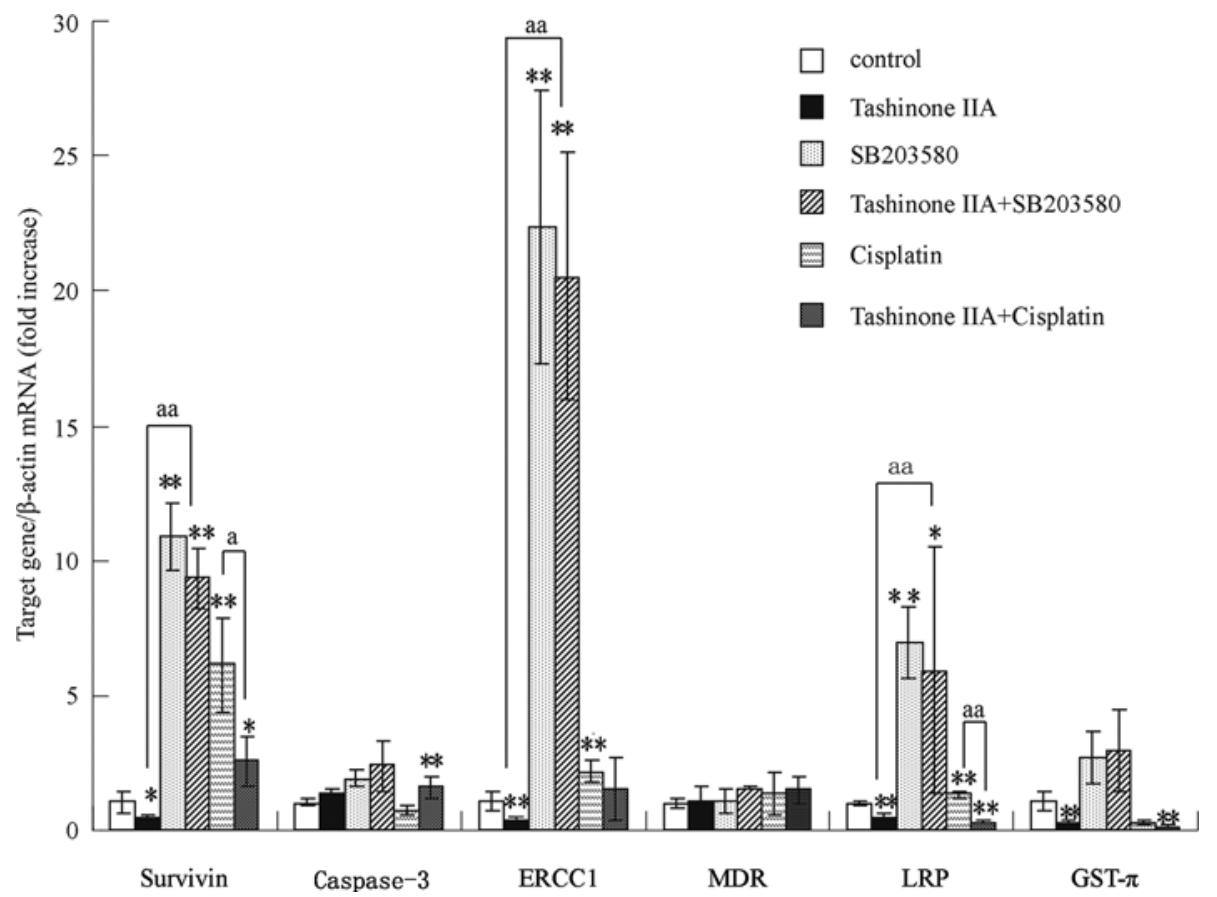

Figure 8. Expression of survivin, Caspase-3, ERCC1, MDR, LRP and GST- $\pi$ mRNA expression in COC1/DDP cells following treatment with tanshinone IIA, cisplatin and/or SB203580. We used quantitative RT-PCR to measure the mRNA levels of various drug resistance genes in COC1/DDP cells treated with tanshinone IIA $(8 \mu \mathrm{g} / \mathrm{ml})$, cisplatin $(20 \mu \mathrm{M})$ and/or SB203580 $(10 \mu \mathrm{M})$. Values are expressed as the mean $\pm \mathrm{SD}(\mathrm{n}=3)$. Statistical analysis was by one-way ANOVA followed by least squares difference (LSD) analysis between all columns. ${ }^{*} \mathrm{p}<0.05$ vs. control; ${ }^{* *} \mathrm{p}<0.01 \mathrm{vs}$. control; ${ }^{\mathrm{a}} \mathrm{p}<0.05$ between indicated pairs; ${ }^{a a} \mathrm{p}<0.01$ between indicated pairs.

of inflammatory and cardiac diseases. Previous studies have shown that tanshinone IIA has a large variety of pharmacological activities such as inhibition of clotting (16), inhibition of NO synthase (17) and dose-dependent inhibition of the basic fibroblast growth factor (bFGF)-induced human smooth muscle cell (SMC) proliferation (18). Recent data have demonstrated that tanshinone IIA has anti-cancer activity on a large variety of cancer cells including solid tumors $(12,13)$ as well as certain types of leukemia cells $(14,19)$. Tanshinone IIA has also been reported to induce apoptosis in human liver cancer cells via a p38-mediated mechanism of upregulated Fas/Caspase-3 expression (20). However, the molecular mechanism underlying the chemopreventive effect of tanshinone IIA has not been fully elucidated.

In this study, we found that tanshinone IIA inhibited the growth of cisplatin-resistant human ovarian cancer COC1/ DDP cells and caused significant apoptosis in a time- and dose-dependent manner. Marked changes in cell apoptosis were clearly observed after the cells had been exposed to tanshinone IIA $(8 \mu \mathrm{g} / \mathrm{ml})$ for $48 \mathrm{~h}$. Tanshinone IIA signi- 
ficantly reduced the resistance index (RI) for cisplatin of COC1/DDP cells, and the apoptotic rate was considerably higher $(>50 \%)$ than that without tanshinone IIA. Western blotting showed that increases in the phosphorylation of $\mathrm{p} 38$ MAPK in COC1/DDP cells was also stimulated by tanshinone IIA in a time- and dose-dependent manner. The p38 MAPK pathway is implicated in cancer cell apoptosis and is induced by several chemotherapeutic drugs including cisplatin (21). The mechanism of p38 MAPK downstream signaling to apoptosis has long been studied, including the involvement of the p38/p53/p21 pathway (22-25), the Bcl-2 family $(26,27)$ and the Fas/FasL pathway (28). Studies on the mechanism of p38 MAPK actions resulting in cisplatin-resistance have focused mainly on cell apoptosis, but have neglected to assess the effects of this signaling system on the expression of genes related with resistance. In our study, we examined the mRNA expression of the survivin, Caspase-3, ERCC1, MDR, GST- $\pi$ and LRP. We found that after treatment with tanshinone IIA $(8 \mu \mathrm{g} / \mathrm{ml}$ for $48 \mathrm{~h})$, mRNA expressions of survivin, ERCC1, GST- $\pi$ and LRP were downregulated, while Caspase-3 and MDR were not. When SB203580 (10 $\mu \mathrm{M})$ was included, it significantly blocked these effects of tanshinone IIA. We therefore concluded that the cell apoptosis induced by tanshinone IIA was caused by the downregulation of surviving, and the decreased RI of COC1/DDP cells for cisplatin was induced by downregulation of the resistance genes ERCC1 and LRP via p38 MAPK.

Survivin, a member of the apoptosis inhibitor family, is expressed in most human malignancies and is implicated in mitosis regulation and preservation of cell viability (29). Previous data have revealed that survivin is one of the genes most consistently over-expressed in tumor cells and plays important roles in both cell proliferation and cell death (30). Downregulation of survivin expression may lead to programmed cell death (31), indicating that it may be an appealing new target for novel therapy in cancer (32). Our results show that tanshinone IIA may trigger apoptosis in COC1/DDP cells by downregulating survivin levels via activation of p38 MAPK. Activated p38 MAPK might therefore inhibit the expression of survivin.

ERCC1 is a rate-limiting DNA repair protein in the nucleotide excision repair pathway that recognizes and removes cisplatin-induced DNA adducts (33-36). ERCC1 is also important for repairing interstrand cross-links in the DNA and in recombination processes (37-39). In ovarian cancer, ERCC1 expression was shown to be increased in the tumors of patients resistant to platinum treatment $(40,41)$. Our results revealed that tanshinone IIA treatment of cisplatinresistant human ovarian cancer COC1/DDP cells caused downregulation of the expression of ERCC1 mRNA in a p38 MAPK-dependent manner. We conclude that tanshinone IIAinduced activation of p38 MAPK might inhibit the expression of ERCC1 protein in cisplatin-resistant human ovarian cancer cells.

LRP has been identified as the major human vault protein (42). Structural studies of vaults have indicated that these may play a role in cytoplasmic redistribution and the nucleocytoplasmic transport of various substrates. LRP has been reported to be a marker for drug resistance in vitro, both for MDR-related drugs (doxorubicin, vincristine) and for other agents (cisplatin, carboplatin and melphalan) (43). In this study, our results showed that tanshinone IIA treatment of COC1/DDP cells downregulated the expression of LRP via p38 MAPK. We conclude that tanshinone IIA-induced activation of p38 MAPK might inhibit the expression of LRP protein in cisplatin-resistant human ovarian cancer cells.

In summary, our results demonstrate that tanshinone IIA has significant anti-proliferative effects on cisplatin-resistant human ovarian cancer COC1/DDP cells by inducing apoptosis and downregulating cisplatin-resistance genes. Tanshinone IIA-induced apoptosis in COC1/DDP cells is mainly related to the downregulation of the anti-apoptotic protein, survivin, and decreased cisplatin-resistance was caused by the downregulation of the resistance genes, ERCC1 and LRP, via p38 MAPK. These results indicate that tanshinone IIA may serve as a potential therapeutic agent for the treatment of cisplatinresistant human ovarian cancer.

\section{References}

1. McClay EF, Albright KD, Jones JA, Eastman A, Christen R and Howell SB: Modulation of cisplatin resistance in human malignant melanoma cells. Cancer Res 52: 6790-6796, 1992.

2. McClay EF, Albright KD, Jones JA, Christen RD and Howell SB: Tamoxifen modulation of cisplatin sensitivity in human malignant melanoma cells. Cancer Res 53: 1571-1576, 1993.

3. Cannistra SA: Cancer of the ovary. N Engl J Med 351: 2519-2529, 2004.

4. Kelland LR: Emerging drugs for ovarian cancer. Expert Opin Emerg Drugs 10: 413-424, 2005.

5. Manic S, Gatti L, Carenini N, Fumagalli G, Zunino F and Perego P: Mechanisms controlling sensitivity to platinum complexes: role of p53 and DNA mismatch repair. Curr Cancer Drug Targets 3: 21-29, 2003.

6. Rabik CA and Dolan ME: Molecular mechanisms of resistance and toxicity associated with platinating agents. Cancer Treat Rev 33: 9-23, 2007.

7. Losa JH, Parada Cobo C, Viniegra JG, Sánchez-Arevalo Lobo VJ, Ramón y Cajal S and Sánchez-Prieto R: Role of the p38 MAPK pathway in cisplatin-based therapy. Oncogene 22: 3998-4006, 2003.

8. Hanahan D and Weinberg RA: The hallmarks of cancer. Cell 100: 57-70, 2000.

9. Wang AM, Sha SH, Lesniak W and Schacht J: Tanshinone (Salviae miltiorrhizae extract) preparations attenuate aminoglycoside-induced free radical formation in vitro and ototoxicity in vivo. Antimicrob Agents Chemother 47: 1836-1841, 2003.

10. Yang LJ, Jeng CJ, Kung HN, Chang CC, Wang AG, Chau GY, Don MJ and Chau YP: Tanshinone IIA isolated from Salvia miltiorrhiza elicits the cell death of human endothelial cells. J Biomed Sci 12: 347-361, 2005.

11. Choi HS, Cho DI, Choi HK, Im SY, Ryu SY and Kim KM: Molecular mechanisms of inhibitory activities of tanshinones on lipopolysaccharide-induced nitric oxide generation in RAW 264.7 cells. Arch Pharm Res 27: 1233-1237, 2004.

12. Wang X, Wei Y, Yuan S, Liu G, Lu Y, Zhang J and Wang W: Potential anticancer activity of tanshinone IIA against human breast cancer. Int J Cancer 116: 799-807, 2005.

13. Yuan SL, Wei YQ, Wang XJ, Xiao F, Li SF and Zhang J: Growth inhibition and apoptosis induction of tanshinone II-A on human hepatocellular carcinoma cells. World J Gastroenterol 10: 2024-2028, 2004.

14. Liu JJ, Zhang Y, Lin DJ and Xiao RZ: Tanshinone IIA inhibits leukemia THP-1 cell growth by induction of apoptosis. Oncol Rep 21: 1075-1081, 2009.

15. Tewari KS and Monk BJ: Gynecologic oncology group trials of chemotherapy for metastatic and recurrent cervical cancer. Curr Oncol Rep 7: 419-434 2005.

16. Chan TY: Interaction between warfarin and danshen (Salvia miltiorrhiza). Ann Pharmacother 35: 501-504, 2001.

17. Yokozawa $\mathrm{T}$ and Chen $\mathrm{CP}$ : Role of Salvia miltiorrhiza radix extract and its compounds in enhancing nitric oxide expression. Phytomedicine 7: 55-61, 2000. 
18. Zhou GY, Zhao BL, Hou JW, Ma GE and Xin WJ: Protective effects of sodium tanshinone IIA sulphonate against adriamycininduced lipid peroxidation in mice hearts in vivo and in vitro. Pharmacol Res 40: 487-491, 1999.

19. Mosaddik MA: In vitro cytotoxicity of tanshinones isolated from Salvia miltiorrhiza bunge against P388 lymphocytic leukemia cells. Phytomedicine 10: 682-685, 2003.

20. Wang Y, Li Q, Fan ZZ, Sun J, Wang YQ, Liu RH and Gao H: Tanshinone IIA induces apoptosis of liver cancer cells via p38MAPK signal transduction. Shi Jie Hua Ren Xiao Hua Za Zhi 17: 124-129, 2009.

21. Bulavin DV and Fornace AJ Jr: p38 MAP kinase's emerging role as a tumor suppressor. Adv Cancer Res 92: 95-118, 2004.

22. Kuribayashi K and El-Deiry WS: Regulation of programmed cell death by the p53 pathway. Adv Exp Med Biol 615: 201-221, 2008.

23. el-Deiry WS, Harper JW, O'Connor PM, VelculescuVE, Canman CE, Jackman J, Pietenpol JA, Burrell M, Hill DE and Wang Y: WAF1/CIP1 is induced in p53-mediated G1 arrest and apoptosis. Cancer Res 54: 1169-1174, 1994.

24. Chen WJ, Chang CY and Lin JK: Induction of G1 phase arrest in MCF human breast cancer cells by pentagalloylglucose through the down-regulation of CDK4 and CDK2 activities and up-regulation of the CDK inhibitors p27(Kip)and p21(Cip). Biochem Pharmacol 65: 1777-1785, 2003.

25. Wong SH, Shih RS, Schoene NW and Lei KY: Zinc-induced G2/M blockage is p53 and p21 dependent in normal human bronchial epithelial cells. Am J Physiol Cell Physiol 294: C1342-C1349, 2008.

26. Maxwell SA, Acosta SA and Davis GE: Induction and alternative splicing of the Bax gene mediated byp53 in a transformed endothelial cell line. Apoptosis 4: 109-114, 1999.

27. Martinez-Caballero S, Dejean LM, Jonas EA and Kinnally KW: The role of the mitochondrial apoptosis induced channel MAC in cytochrome c release. J Bioenerg Biomembr 37: 155-164, 2005.

28. Kornmann M, Ishiwata T, Kleeff J, Beger HG and Korc M: Fas and fas-ligand expression in human pancreatic cancer. Ann Surg 231: 368-379, 2000.

29. Morinaga S, Nakamura Y, Ishiwa N, Yoshikawa T, Noguchi Y, Yamamoto Y, Rino Y, Imada T, Takanashi Y, Akaike M, Sugimasa $Y$ and Takemiya S: Expression of survivin mRNA associates with apoptosis, proliferation and histologically aggressive features in hepatocellular carcinoma. Oncol Rep 12: 1189-1194, 2004.

30. Nakao K, Hamasaki K, Ichikawa T, Arima K, Eguchi K and Ishii N: Survivin downregulation by siRNA sensitizes human hepatoma cells to TRAIL-induced apoptosis. Oncol Rep 16: 389-392, 2006.

31. Wang J, Xu Z and Zhang M: Downregulation of survivin expression and elevation of caspase- 3 activity involved in pitavastatin-induced HepG 2 cell apoptosis. Oncol Rep 18: 383-387, 2007.
32. Giannetti L, Consolo U, Magnoni C and Lo Muzio L: Apoptosis: escaping strategies in human skin cancer (Review). Oncol Rep 11: 401-405, 2004.

33. Bepler G, Gautam A, McIntyre LM, Beck AF, Chervinsky DS, Kim YC, Pitterle DM and Hyland A: Prognostic significance of molecular genetic aberrations on chromosome segment $11 \mathrm{p} 15.5$ in non-small-cell lung cancer. J Clin Oncol 20: 1353-1360. 2002.

34. Mu D, Hsu DS and Sancar A: Reaction mechanism of human DNA repair excision nuclease. J Biol Chem 271: 8285-8294, 1996.

35. Sancar A: Mechanisms of DNA excision repair. Science 266: 1954-1956, 1994.

36. Zamble DB, Mu D, Reardon JT, Sancar A and Lippard SJ: Repair of cisplatin-DNA adducts by the mammalian excision nuclease. Biochemistry 35: 10004-10013, 1996.

37. De Silva IU, McHugh PJ, Clingen PH and Hartley JA: Defining the roles of nucleotide excision repair and recombination in the repair of DNA interstrand cross-links in mammalian cells. Mol Cell Biol 20: 7980-7990, 2000.

38. Niedernhofer LJ, Odijk H, Budzowska M, van Drunen E, Maas A, Theil AF, de Wit J, Jaspers NG, Beverloo HB, Hoeijmakers JH and Kanaar R: The structure-specific endonuclease Ercc1-Xpf is required to resolve DNA interstrand cross-link-induced doublestrand breaks. Mol Cell Biol 24: 5776-5787, 2004.

39. Sargent RG, Meservy JL, Perkins BD, Kilburn AE, Intody Z, Adair GM, Nairn RS and Wilson JH: Role of the nucleotide excision repair gene ERCC1 in formation of recombinationdependent rearrangements in mammalian cells. Nucleic Acids Res 28: 3771-3778, 2000.

40. Dabholkar M, Vionnet J, Bostick-Bruton F, Yu JJ and Reed E: Messenger RNA levels of XPAC and ERCC1 in ovarian cancer tissue correlate with response to platinum-based chemotherapy. J Clin Invest 94: 703-708, 1994.

41. Li Q, Yu JJ, Mu C, Yunmbam MK, Slavsky D, Cross CL, Bostick-Bruton F and Reed E: Association between the level of ERCC-1 expression and the repair of cisplatin-induced DNA damage in human ovarian cancer cells. Anticancer Res 20: 645-652, 2000.

42. Scheffer GL, Wijngaard PLJ, Flens MJ, Izquierdo MA, Slovak ML, Pinedo HM, Meijer CJLM, Clevers HC and Scheper RJ: The drug resistance-related protein LRP is the human major vault protein. Nat Med 1: 578-582, 1995.

43. List AF, Spier CS, Grogan TM, Johnson C, Roe DJ, Greer JP, Wolff SN, Broxterman HJ, Scheffer GL, Scheper RJ and Dalton WS: Over expression of the major vault transporter protein lung-resistance protein predicts treatment outcome in acute myeloid leukemia. Blood 87: 2464-2469, 1996. 